\title{
Extracellular ATP is a pro-angiogenic factor for pulmonary artery vasa vasorum endothelial cells
}

\author{
Evgenia V. Gerasimovskaya · Heather N. Woodward • \\ Doug A. Tucker · Kurt R. Stenmark
}

Received: 7 July 2007 / Accepted: 26 November 2007 / Published online: 11 December 2007

(C) The Author(s) 2007

\begin{abstract}
Expansion of the vasa vasorum network has been observed in a variety of systemic and pulmonary vascular diseases. We recently reported that a marked expansion of the vasa vasorum network occurs in the pulmonary artery adventitia of chronically hypoxic calves. Since hypoxia has been shown to stimulate ATP release from both vascular resident as well as circulatory blood cells, these studies were undertaken to determine if extracellular ATP exerts angiogenic effects on isolated vasa vasorum endothelial cells (VVEC) and/or if it augments the effects of other angiogenic factors (VEGF and basic FGF) known to be present in the hypoxic microenvironment. We found that extracellular ATP dramatically increases DNA synthesis, migration, and rearrangement into tube-like networks on Matrigel in VVEC, but not in pulmonary artery (MPAEC) or aortic (AOEC) endothelial cells obtained from the same animals. Extracellular ATP potentiated the effects of both VEGF and bFGF to stimulate DNA synthesis in VVEC but not in MPAEC and
\end{abstract}

Preliminary results were presented at Aspen Lung Conference, 47th Annual Meeting, June 6-9, Aspen, CO, 2004; at the 8th International Symposium of Adenosine and Adenine Nucleotides, May 24-28, 2006, Ferrara, Italy; and at the American Thoracic Society Annual Meeting, May 23-28, San Francisco, CA, 2007.

E. V. Gerasimovskaya $(\bowtie) \cdot$ H. N. Woodward .

D. A. Tucker · K. R. Stenmark

Department of Pediatrics, University of Colorado at Denver and

Health Sciences Center, B131, 4200 East 9th Ave, Denver, CO 80262, USA

e-mail: Evgenia.Gerasimovskaya@UCHSC.edu

Present Address:

D. A. Tucker

College of Osteopathic Medicine of the Pacific, Western

University of Health Sciences, Pomona, CA 91766, USA
AOEC. Analysis of purine and pyrimidine nucleotides revealed that ATP, ADP and MeSADP were the most potent in stimulating mitogenic responses in VVEC, indicating the involvement of the family of P2Y1-like purinergic receptors. Using pharmacological inhibitors, Western blot analysis, and Phosphatidylinositol-3 kinase (PI3K) in vitro kinase assays, we found that PI3K/Akt/ mTOR and ERK1/2 play a critical role in mediating the extracellular ATP-induced mitogenic and migratory responses in VVEC. However, PI3K/Akt and mTOR/ p70S6K do not significantly contribute to extracellular ATP-induced tube formation on Matrigel. Our studies indicate that VVEC, isolated from the sites of active angiogenesis, exhibit distinct functional responses to ATP, compared to endothelial cells derived from large pulmonary or systemic vessels. Collectively, our data support the idea that extracellular ATP participates in the expansion of the vasa vasorum that can be observed in hypoxic conditions.

Keywords Angiogenesis - Endothelial cells · ERK1/2 · Extracellular ATP · Hypoxia · mTOR .

Phosphatidylinositol-3 kinase - Signal transduction ·

Vasa vasorum · Vascular remodeling

\section{Introduction}

Angiogenesis, the formation of new capillaries from preexisting blood vessels, occurs during normal embryonic development and in various pathological conditions where hypoxia, ischemia, or inflammation are prominent features $[1,2]$. In a neonatal model of hypoxic pulmonary hypertension, we have demonstrated that adventitial thickening and expansion of the vasa vasorum network, are especially 
prominent components of the pulmonary vascular remodeling process $[3,4]$. In the pulmonary arteries, the vasa vasorum is the microcirculatory network of the bronchial (systemic) circulation and, similar to its role in systemic vessels, is thought to contribute to vascular integrity through supply of oxygen and nutrients to the outer part of the vessel wall. However, an increasing body of experimental data has demonstrated that the expansion of the vasa vasorum might also contribute to the progression of certain vascular diseases in systemic circulation including atherosclerosis, restenosis, and vasculitis, suggesting that neovascularization of the vasa vasorum might be an important common feature of specific pulmonary and systemic vascular diseases [5-7]. At present, the precise cellular mechanisms and endogenous molecular factors contributing to this process of neovascularization in the vessel wall are not completely understood.

Endogenous soluble autocrine and paracrine factors released under hypoxic conditions from cells of the vascular wall and circulating blood cells are important contributors to angiogenesis [8-12]. Extracellular purine and pyrimidine nucleotides ATP, ADP, AMP, UTP, UDP act as ligands for P2Y (metabotropic) and P2X (ionotropic) purinergic receptors and are increasingly recognized as important regulators of a variety vascular functions, including vascular tone, permeability, inflammation, and thrombosis [13-16]. Elevated concentrations of extracellular ATP are thought to be present in the local microenvironment in various physiological and pathological conditions including hypoxia, thrombosis, sympathetic stimulation (when ATP is co-released with noradrenalin), and tissue damage, suggesting that different types of stress conditions could contribute to elevated extracellular ATP levels in the vascular wall. A number of studies support the idea that extracellular nucleotides could contribute to the development of vascular disease. Extracellular ATP has been implicated in the hyperplasia and hypertrophy of arterial walls in spontaneously hypertensive rats [17], in the regulation of vascular permeability [18, 19], and in the control of proliferation and migration of vascular smooth muscle cells and hematopoietic stem cells [20-23]. For example, purinergic antithrombotic drugs reduce the risk of recurrent strokes and heart attacks [24]. Further, in endothelial cells, ATP- and UTP-induced stimulation of P2Y2 receptors is associated with the co-activation of VEGF receptor-2, expression of Vascular Cell Adhesion Molecule-1 (VCAM-1), and monocyte recruitment, implying a link between purinergic signaling, angiogenesis, and inflammatory responses $[25,26]$. A product of extracellular ATP hydrolysis, adenosine, has been shown to be angiogenic for both microvascular and macrovascular endothelial cells [27-29]. Importantly, ATP has been reported to act synergistically with cytokines (e.g., platelet- derived growth factor, epidermal growth factor, and insulin-like growth factor) and integrins to stimulate vascular cell proliferation and migration, thereby increasing the potential importance of extracellular ATP under various pathologic conditions [20, 30-32]. However, a role for extracellular ATP in the angiogenic process has not been established.

Since chronic hypoxic exposure stimulates angiogenesis of the pulmonary artery vasa vasorum in neonatal calves but not, to our knowledge, of other vascular beds in the same animals, and because hypoxia has been shown to stimulate release of ATP from bovine neonatal endothelial cells, the purpose of this study was to determine whether extracellular ATP exerts angiogenic effects on vasa vasorum endothelial cells that were distinct from pulmonary artery or aortic endothelial cells, and to determine the signaling pathways utilized in these responses. Using established cultures of vasa vasorum endothelial cells (VVEC) isolated from PA adventitia of chronically hypoxic animals as well as pulmonary artery and aortic endothelial cells derived from the same animals, we compared the effects of ATP and other purine and pyrimidine nucleotides on various parameters associated with angiogenesis such as proliferation, migration, and tube formation on Matrigel. We also assessed the effects of known angiogenic factors with and without extracellular ATP on mitogenesis in these cell types. We also sought to define the signaling pathways through which these effects were mediated. Based on preliminary data and findings in other cell types, emphasis was placed on the PI3K/Akt, mTOR/ p70S6K and ERK1/2 pathways.

\section{Materials and methods}

Cultures of vasa vasorum endothelial cell from pulmonary artery adventitia

Pulmonary artery adventitia was dissected from the media, extensively washed from blood in phosphate-buffered saline solution (PBS), and enzymatically digested for $1.5-2 \mathrm{~h}$ at $37^{\circ} \mathrm{C}$ in a mixture containing collagenase type 2 $(0.5 \mathrm{mg} / \mathrm{ml})$, elastase $(0.5 \mathrm{mg} / \mathrm{ml})$, bovine albumin $(2 \mathrm{mg} /$ $\mathrm{ml})$, and soybean trypsin inhibitor $(0.02 \mathrm{mg} / \mathrm{ml})$. Dispersed cell mixtures were filtered through a $100 \mu \mathrm{M}$ nylon cell strainer (BD Biosciences, San Diego, CA), plated on 6-well plates and grown in DMEM media supplemented with $10 \%$ fetal bovine serum (FBS) and Endothelial Growth Supplement (Upstate Biotechnology, Charlottesville, VA). VVEC were purified from the co-cultures with adventitial fibroblasts using cloning rings and trypsinization techniques. Isolated VVEC have been shown to express endothelial markers, including vWF, eNOS, and PECAM-1; 
binding of the lectin Licopercsicon Esculentum; and incorporate acetylated low-density lipoproteins labeled with 1,1'-dioctadecyl-3,3,3',3'-tetramethylindo-carbocyanine perchlorate (DiI-Ac-LDL) [33, 34].

\section{DNA synthesis}

DNA synthesis was determined by $\left[\right.$ methyl $\left.-{ }^{3} \mathrm{H}\right]$ thymidine incorporation previously performed by Gerasimovskaya et al. [31]. Cells were plated in 24-well plates at a density of 12,000 cells per well in DMEM, supplemented with $10 \%$ FBS. On the next day cells were rinsed with phosphate-buffered saline (PBS), and incubated in DMEM without serum for $72 \mathrm{~h}$. Cells were stimulated with extracellular ATP $\left(10^{-9}-10^{-3} \mathrm{M}\right)$, VEGF $(10 \mathrm{ng} / \mathrm{ml})$, basic FGF (bFGF, $10 \mathrm{ng} / \mathrm{ml}$ ), ATP and VEGF, or ATP and bFGF as indicated in the figure legends. In the experiments designed to evaluate a role of PI3K, mTOR, and ERK1/2 pathways, cells were pre incubated with or without LY294002 (20 $\mu \mathrm{M}, 60 \mathrm{~min})$, wortmannin (100 nM 2-6 h), rapamycin $(10 \mathrm{nM}, 60 \mathrm{~min})$, or U0126 $(10 \mu \mathrm{M}, 60 \mathrm{~min})$ (Cell Signaling, Danvers, MA) and then stimulated with $\operatorname{ATP}(100 \mu \mathrm{M})$ in the presence of $0.125 \mu \mathrm{Ci}$ of [methyl- ${ }^{3} \mathrm{H}$ ] thymidine (NEN Life Science Products, Boston, MA), for $24 \mathrm{~h}$. To stop the incubation, VVEC were washed twice with $1 \mathrm{ml}$ of PBS, incubated with $0.5 \mathrm{ml}$ of $0.2 \mathrm{M}$ perchloric acid for $3 \mathrm{~min}$, washed with PBS, and lysed in $0.3 \mathrm{ml}$ of $1 \%$ SDS containing $0.1 \mathrm{M} \mathrm{NaOH}$. Thereafter samples were harvested, mixed with liquid scintillation cocktail (Ecoscint H, National Diagnostics, Atlanta, GA), and incorporated [methyl- ${ }^{3} \mathrm{H}$ ] thymidine was counted $(\mathrm{cpm} / \mathrm{min})$ in a scintillation $\beta$-counter (Beckman LS 6500).

\section{Migration assay}

Growth-arrested cells (VVEC, AOEC, or MPAEC, 100,000 cells/well) were plated in $200 \mu \mathrm{l}$ of serum-free DMEM in permeable cell culture inserts (polycarbonate membrane, $8.0 \mu \mathrm{M}$ pore size, Falcon ${ }^{\mathrm{TM}}$ ) precoated with $0.1 \%$ gelatin (Sigma, St. Louis, MO). ATP $(100 \mu \mathrm{M})$ was added in the lower chamber containing $800 \mu \mathrm{l}$ of serumfree DMEM. In some of the experiments, the effect of ATP on endothelial cell migration was determined in the media, supplemented with $2 \%$ fetal bovine serum. To evaluate the contribution of PI3K, mTOR, and ERK1/2 pathways to VVEC migration, cells in transwells were pre incubated with LY294002 $(20 \mu \mathrm{M})$, wortmannin $(100 \mathrm{nM})$, rapamycin $(10 \mathrm{nM})$, or U0126 $(10 \mu \mathrm{M})$ for $60 \mathrm{~min}$. After $24 \mathrm{~h}$ incubation, cells remaining on the upper surface of the filter were wiped off, and migrated cells were fixed with methanol for $15 \mathrm{~min}$ and stained with $0.2 \%$ crystal violet in
$2 \%$ (v/v) ethanol for a minimum of $15 \mathrm{~min}$. Cell migrated through filter were photographed under $40 \times$ magnification of a phase contrast microscope in six random fields.

In vitro Matrigel assay

The Matrigel in vitro tube-formation assay was performed using Growth Factor-Reduced (GFR) Basement Membrane Matrix (BD Bioscience, Bedford, MA). Matrigel (300 $\mu \mathrm{l} /$ well) was polymerized in 24-well plates for $60 \mathrm{~min}$ at $37^{\circ} \mathrm{C}$. Growth-arrested VVEC $(125,000$ cells/well) were plated on top of Matrigel either with or without inhibitors of PI3K, mTOR, or ERK1/2. After 60 min incubation, ATP $(100 \mu \mathrm{M})$ was added to the half of the wells. When AOEC and MPAEC were tested, both cell types were plated at the density 200,000 cells/well in 24-well plates and incubated either with or without ATP $(100 \mu \mathrm{M})$. Tube formation was visualized after $8-10 \mathrm{~h}$ of incubation with a $\times 40$ objective with a phase contrast microscope (Nikon) equipped with digital camera. For each experimental condition, three images were captured. Tube length and area of cell aggregates were quantified using AxioVision (Zeiss). Both parameters were measured using the length tool. Data are presented in pixels.

\section{In vitro PI3K activity assay}

Endothelial cells were cultured to $80 \%$ confluence in $100 \mathrm{~mm}^{2}$ dishes, growth-arrested in DMEM without serum for $72 \mathrm{~h}$ and then stimulated with ATP $(100 \mu \mathrm{M})$ or FBS (10\%) for $30 \mathrm{~min}$. After stimulation, cells were washed two times with ice-cold PBS, containing $0.2 \mathrm{mM}$ activated orthovanadate, and incubated in $750 \mu \mathrm{l}$ of lysis buffer, containing $137 \mathrm{mM} \mathrm{NaCl}, 20 \mathrm{mM}$ Tris- $\mathrm{HCl}, \mathrm{pH} 7.5$, $1 \mathrm{mM} \mathrm{MgCl}_{2}, 1 \mathrm{mM} \mathrm{CaCl}_{2}, 10 \%$ glycerol, $1 \%$ Nonidet P$40,1 \mathrm{mM}$ sodium orthovanadate, $1 \mathrm{mM}$ PMSF, and complete protease inhibitor cocktail (Calbiochem, La Jolla, CA) and incubated for $20 \mathrm{~min}$ at $+4^{\circ} \mathrm{C}$. Cell lysates were transferred to $1.5 \mathrm{ml}$ tubes and centrifuged at $10,000 \mathrm{~g}$ for $10 \mathrm{~min}$ to sediment-insoluble material. Supernatants were normalized for protein content (Bio-Rad protein assay kit) and $\mathrm{PI} 3 \mathrm{~K}$ was immunoprecipitated using the Catch and Release $^{\mathrm{TM}}$ immunoprecipitation system (Upstate Biotechnology). The phosphorylation reaction (final volume $80 \mu \mathrm{l}$ ) was started by addition of $10 \mu \mathrm{l}$ of mixture, containing $15 \mu \mathrm{Ci}\left[\gamma^{32} \mathrm{P}\right]$ ATP $(10 \mathrm{mM}, 3,000 \mathrm{Ci} / \mathrm{mmol})$ and $0.88 \mu \mathrm{l}$ of $10 \mathrm{mM}$ ATP to $50 \mu \mathrm{l}$ of eluate containing PI3K. The samples were incubated for $15 \mathrm{~min}$ at $37^{\circ} \mathrm{C}$, and the reaction was stopped by the addition of $20 \mu \mathrm{l}$ of $6 \mathrm{~N} \mathrm{HCl}$. Radiolabeled lipids were extracted with $160 \mu \mathrm{l}$ of chloroform-methanol mixture (1:1, vol:vol.). The organic phase 
was separated by centrifugation for $10 \mathrm{~min}$ at $12,000 \mathrm{~g}$ at $4^{\circ} \mathrm{C}$, and lipids were separated on oxalate-coated silicon TLC plates (Silica Gel 60, Sigma) by chromatography in a $\mathrm{CH}_{3}$ : $\mathrm{MeOH}: \mathrm{H}_{2} \mathrm{O}: \mathrm{NH}_{4} \mathrm{OH}$ (60:40:11.3:2 by vol.) solvent system in parallel with a non-radioactive standard.

\section{Cell extracts and Western blot analysis}

VVEC were cultured to near confluence and serum -starved in DMEM for 48-72 h. For the experiments with PI3K, mTOR and ERK1/2 inhibitors cells were pre incubated with LY294002, wortmannin, rapamycin, or U0126, as described in the figure legends. Cells were stimulated with ATP $(100 \mu \mathrm{M})$ in serum-free media for variable periods of time. After stimulation, VVEC were washed twice with ice-cold PBS and lysed with Tris- $\mathrm{HCl}$ buffer $(40 \mathrm{mM}$ $\left.\mathrm{pH} 7.5,4^{\circ} \mathrm{C}\right)$, containing $0.1 \%$ Triton $\mathrm{X}-100,0.25 \mathrm{M}$ sucrose, $3 \mathrm{mM}$ EGTA, $3 \mathrm{mM}$ EDTA, $50 \mu \mathrm{M} \beta$-mercaptoethanol, $1 \mathrm{mM}$ PMSF and complete protease inhibitor cocktail (Calbiochem). Cell lysates were centrifuged at $7,500 \mathrm{~g}$ for $10 \mathrm{~min}$ at $+4^{\circ} \mathrm{C}$, and supernatant fractions were collected and stored at $-80^{\circ} \mathrm{C}$. Equivalent amounts of total cell protein $(20-40 \mu \mathrm{g})$ were subjected to $10 \%$ sodium dodecyl sulfate-polyacrylamide gel electrophoresis (SDSPAGE). Proteins were transferred to PVDF membranes and probed with rabbit polyclonal antibodies against phosphoERK1/2 (Tyr202/Thr204), phospho-p70S6K (Thr421/Ser424), phospho-Akt (Ser473), phospho-mTOR (Ser2448), following conditions recommended by the manufacturer (Cell Signaling Technology). After washing with TBS-Tween buffer, membranes were incubated with donkey anti-rabbit peroxidase-conjugated IgG 1:20,000 dilution, (Amersham Bioscienses, Piscataway, $\mathrm{NJ}$ ), for $1 \mathrm{~h}$ at room temperature. Immunoreactive bands were detected by ECL kit (Renaissance, NEN Life Science Product) followed by exposure to Hyperfilm. In all experiments, equivalent sample loading and transfer was verified by staining PVDF membrane with Ponseau or probing with antibodies against non-phosphorylated form of indicated proteins or $\beta$-actin.

\section{Statistical analysis}

Data are expressed as mean \pm standard error (SE); $n$ equals the number of replicates in one experiment or a number of observations in independent experiments. To evaluate significance of the obtained data, Student-Newman-Keuls or Bonferroni tests followed by one-way ANOVA were performed using GraphPad Prism 3.0 (GraphPad Software). A value of $P<0.05$ was considered statistically significant.

\section{Results}

Extracellular ATP stimulates DNA synthesis in VVEC, but not in AOEC or MPAEC

Several lines of evidence have demonstrated that in response to hypoxia, endothelial cells of both pulmonary and systemic vessels release ATP into the extracellular space $[13,17,34,35]$. The effects of the released extracellular ATP on endothelial function have not been fully elucidated. Specifically, whether extracellular ATP is directly involved in endothelial angiogenesis remains unexplored. To address this question, we examined the effect of extracellular ATP on DNA synthesis in VVEC as well as main pulmonary artery (MPAEC) and aortic endothelial cells (AOEC) isolated from the same animals. Extracellular ATP at concentrations of $10^{-6}-10^{-3} \mathrm{M}$ robustly (5-12 fold) increased DNA synthesis in quiescent VVEC (Fig. 1a). The mitogenic effect of extracellular ATP far exceeded those observed in AOEC and MPAEC, where DNA synthesis was only minimally affected (Fig. 1b, c).

Extracellular ATP is rapidly hydrolyzed by endothelial ecto-nucleotidases/NTPDases to ADP, AMP, and adenosine. Since ATP hydrolysis products might be expected to contribute to an increase in DNA synthesis, we examined the effects of various adenine nucleotides, their non-hydrolyzable synthetic analogs, and UTP and UDP on DNA synthesis in VVEC, MPAEC, and AOEC. As shown in Table 1, ATP, ADP, and MeSADP significantly increased [methyl- ${ }^{3} \mathrm{H}$ ] thymidine incorporation in VVEC more than 5-fold. AMP, Ado, ADP $\beta$ S, ATP $\gamma$ S, MeSATP, and $\beta \gamma$ MeATP also had significant effects on [methyl- ${ }^{3} \mathrm{H}$ ] thymidine incorporation with variable potency (2-5 fold). $\alpha \beta$ Me-ATP, BZ-ATP, and $\mathrm{Ap}_{4} \mathrm{~A}$ were not effective. Surprisingly, no significant changes in DNA synthesis were observed in response to pyrimidine nucleotides (UTP and UDP). The efficacy of extracellular nucleotides in increasing DNA synthesis suggests that the P2Y1 family of $\mathrm{G}$ protein-coupled purinergic receptors (P2Y1, P2Y11, $\mathrm{P} 2 \mathrm{Y} 12, \mathrm{P} 2 \mathrm{Y} 13$ ) is likely involved in mediating the effect of extracellular adenine nucleotides in VVEC. As shown in Table 1, UTP, UDP, adenosine, and all tested nucleotide analogs did not have a significant effect on DNA synthesis in AOEC and MPAEC. Thus, VVEC isolated from the sites of active neovascularization exhibit a distinct proliferative phenotype to extracellular adenine nucleotides, particularly, ATP and ADP.

Many growth factors and cytokines known to be involved in angiogenic process including VEGF and bFGF are increased by hypoxia and are present in the hypoxic pulmonary artery microenvironment [33]. Therefore, we next evaluated the effect of VEGF and 

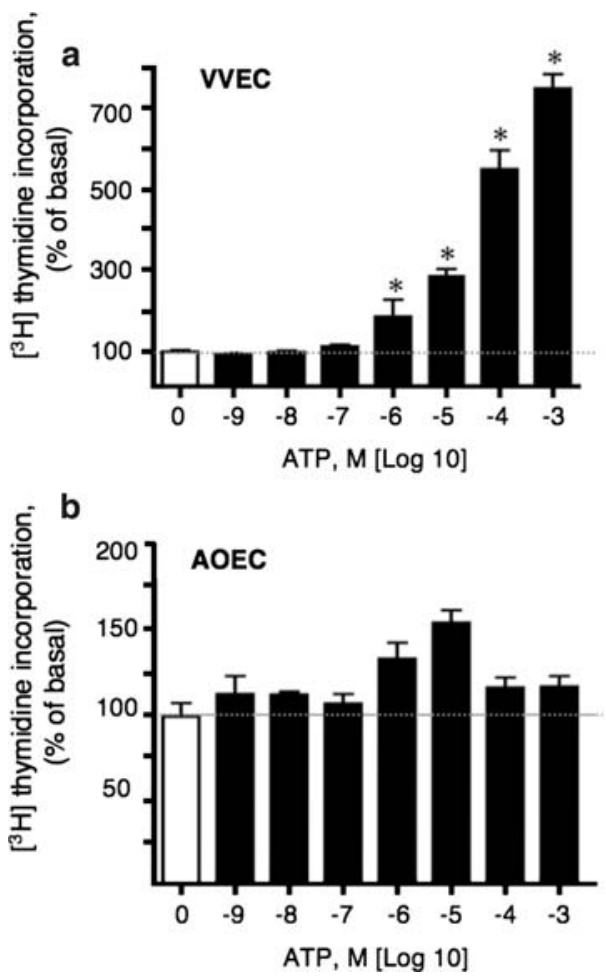

Fig. 1 Extracellular ATP stimulates DNA synthesis in VVEC, but not in AOEC or MPAEC. Growth-arrested (72 h, serum-free DMEM) vasa vasorum endothelial cells (VVEC, Panel a), aorta endothelial cells (AOEC, Panel b), and main pulmonary artery endothelial cells (MPA, Panel c), were stimulated with extracellular ATP from $10^{-9}$ to $10^{-3} \mathrm{M}$ in the presence of $0.125 \mu \mathrm{Ci}\left[{ }^{3} \mathrm{H}\right]$-thymidine for $24 \mathrm{~h}$. Incorporated radioactivity was determined in total cell lysates as

bFGF in the presence and the absence of extracellular ATP, in these cell types of interest. We found that in VVEC, VEGF induced about 2.4-fold increase in DNA synthesis (Fig. 2). In these cells, the response to VEGF was potentiated by simultaneous stimulation with extracellular ATP. In AOEC and MPAEC, VEGF induced increases in DNA synthesis by 1.24- and 2.42-fold, respectively, but in contrast to VVEC, co-stimulation with extracellular ATP resulted in only modest potentiation of DNA synthesis (Fig. 2). bFGF induced 5-fold increase in DNA synthesis in VVEC, and in 1.6- and 1.9-fold increases in AOEC and MPAEC, respectively. The responses to bFGF were significantly potentiated by extracellular ATP in VVEC, but not in AOEC and MPAEC. Together, these data demonstrated differential endothelial proliferative responses to stimulation with VFGF and bFGF. Further extracellular ATP potentiates growth factor-mediated responses in a cell type-specific manner. The responses to ATP in combination with growth factors are predetermined by the ability of the endothelial cell to proliferate in response to ATP. c

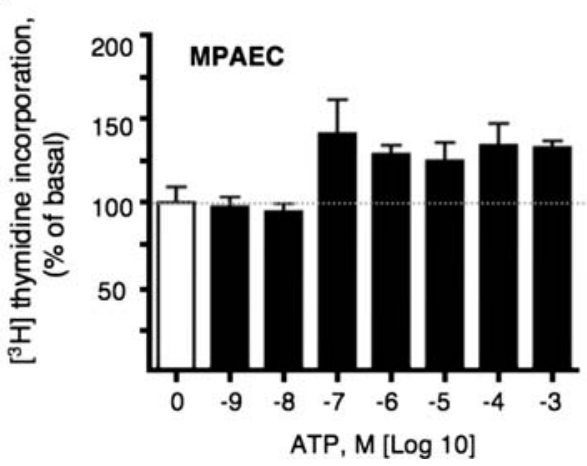

described in MATERIALS AND METHODS. The results are expressed as means $\pm \mathrm{SE} ; * P<0.05$ vs. nonstimulated control $(n=3)$. Please note the different scale of $Y$-axis on Panels a-c. Data illustrate one representative experiment for each cell type. Similar results have been obtained from three to six independent experiments conducted on distinct cell populations

Extracellular ATP induces migration of VVEC but not AOEC and MPAEC

Endothelial cell migration is an important step in the angiogenesis process. Therefore, to further characterize angiogenic responses to extracellular ATP, we examined the effect of ATP on migration of VVEC, AOEC, and MPAEC. Our preliminary observations demonstrated a high migratory capability of VVEC in response to $0.1-10 \%$ fetal bovine serum (FBS). Therefore, elimination of FBS from the media was necessary to assess the direct effect of extracellular ATP on endothelial migration. As shown in Fig. 3, extracellular ATP $(100 \mu \mathrm{M})$ stimulated VVEC migration up to 8-fold. The observed response was comparable in magnitude to the response elicited by $2 \%$ FBS (Fig. 3a, b). Stimulation of VVEC with ATP $(100 \mu \mathrm{M})$ and $2 \%$ FBS had an additive effect on cell migration. However, at a concentration of $5 \%$ or higher, FBS completely masked the effect of extracellular ATP (not shown). No migratory responses to ATP were observed in AOEC and MPAEC under the same experimental conditions where 
Table 1 The effects of purine and pyrimidine nucleotides and nonhydrolyzable nucleotide analogs on DNA synthesis in VVEC, AOEC, and MPAEC

\begin{tabular}{lllc}
\hline Agonist $(100 \mu \mathrm{M})$ & VVEC & AOEC & MPAEC \\
\hline Basal & 100 & 100 & 100 \\
ATP & $560 \pm 112^{* *}$ & $112 \pm 1$ & $116 \pm 10$ \\
ADP & $605 \pm 74^{*}$ & $143 \pm 7$ & $118 \pm 8$ \\
AMP & $488 \pm 72^{*}$ & $141 \pm 8$ & $112 \pm 16$ \\
Ado & $249 \pm 45^{*}$ & $100 \pm 8$ & $96 \pm 44$ \\
ATP $\gamma \mathrm{S}$ & $335 \pm 72^{*}$ & $140 \pm 10$ & $122 \pm 8$ \\
ADP $\beta$ S & $308 \pm 117^{*}$ & $141 \pm 11$ & $114 \pm 12$ \\
UTP & $150 \pm 27$ & $109 \pm 15$ & $80 \pm 14$ \\
UDP & $97 \pm 4$ & $100 \pm 2$ & $79 \pm 11$ \\
MeSATP & $290 \pm 44 *$ & $132 \pm 8$ & $111 \pm 12$ \\
MeSADP & $564 \pm 257 * *$ & ND & $102 \pm 10$ \\
$\alpha \beta$ MeATP & $141 \pm 36$ & $129 \pm 10$ & $114 \pm 9$ \\
$\beta \gamma$ MeATP & $253 \pm 121$ & $126 \pm 8$ & $105 \pm 6$ \\
BzATP & $200 \pm 85$ & $126 \pm 18$ & $91 \pm 14$ \\
Ap 4 A & $198 \pm 58$ & $112 \pm 3$ & $111 \pm 7$ \\
\hline
\end{tabular}

The effect of various nucleotides and nucleotide analogs was evaluated by $\left[\right.$ methyl- $\left.{ }^{3} \mathrm{H}\right]$ thymidine incorporation as described in MATERIALS AND METHODS. Data represents means \pm SE (as \% of nonstimulated control) from three to five independent experiments, conducted on at least four distinct VVEC populations and at least two AOEC and MPAEC populations; $* P<0.05, * * P<0.01$ vs. nonstimulated control

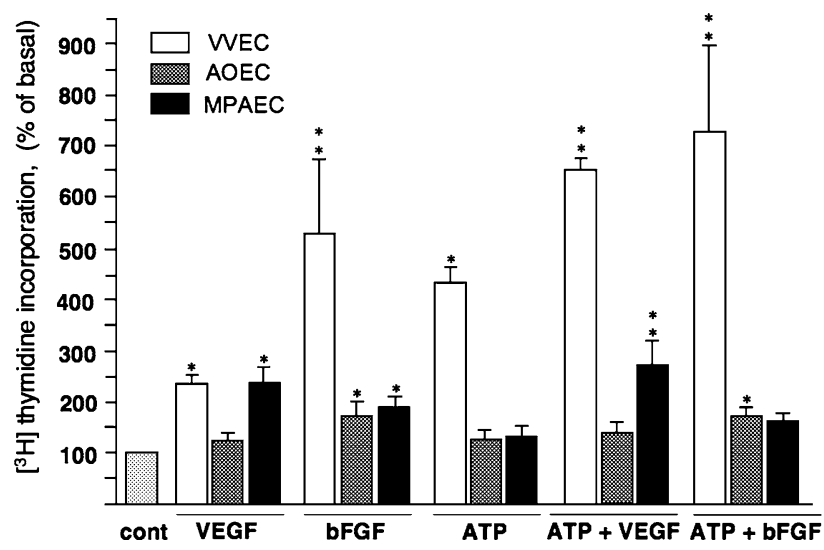

Fig. 2 Effects of VEGF, bFGF with and without ATP on DNA synthesis in VVEC, AOEC, and MPAEC. Growth-arrested (72 h, serum-free DMEM) vasa vasorum endothelial cells (VVEC), aorta endothelial cells (AOEC), and main pulmonary artery endothelial cells (MPA), were stimulated with VEGF (10 ng/ml), bFGF (10 ng/ $\mathrm{ml})$ with or without ATP $(100 \mu \mathrm{M})$ in the presence of $0.125 \mu \mathrm{Ci}\left[{ }^{3} \mathrm{H}\right]-$ thymidine for $24 \mathrm{~h}$. Incorporated radioactivity was determined in total cell lysates as described in MATERIALS AND METHODS. The results are expressed as means $\pm \mathrm{SE} ; * P<0.05$ vs. nonstimulated control. Data represent means $\pm \mathrm{SE}$ (as \% of nonstimulated control) from three to eight independent experiments, conducted on at least three distinct VVEC and two distinct AOEC and MPAEC populations; $* P<0.05, * * P<0.01$ vs. nonstimulated control maximal migratory responses were observed in VVEC (Fig. 3c).

Extracellular ATP induces VVEC but not AOEC and MPAEC rearrangements into tube-like networks on Matrigel

In addition to proliferation and migration, interaction of endothelial cells with extracellular matrix is integral to the angiogenic process. Using an in vitro Matrigel assay, we explored the possibility that incubation of endothelial cells from different sources with ATP would stimulate cell rearrangements into tube-like networks. Plating of quiescent VVEC on growth factor-reduced (GFR) Matrigel in a serum-free media resulted in a pattern of aligned and aggregated cell structures, though no distinguishable network formation was observed within $18 \mathrm{~h}$ of plating (Fig. 4a, -ATP). In the presence of extracellular ATP $(100 \mu \mathrm{M}, 6 \mathrm{~h})$, VVEC assembled in a pattern of tube-like structures (Fig. 4a, +ATP). Calculated areas of total and average tube length increased more than 3 -fold in ATP-stimulated cells (Fig. 4b, d). No significant changes were observed in the total and average diameter of the endothelial cell aggregates (Fig. 4c, e) suggesting a predominant effect of extracellular ATP on cell mobility rather than stabilization of cell-cell and/or cell-matrix interaction. The tube-like structures were stable for 6 and $10 \mathrm{~h}$ followed by the regression between 10 and $18 \mathrm{~h}$.

We found that AOEC and MPAEC rearranged into pattern of tube-like networks within $6 \mathrm{~h}$ of plating on GFR Matrigel (Fig. 4a). In AOEC, extracellular ATP $(100 \mu \mathrm{M})$ induced an approximately two-fold increase in total tube length, but total cell aggregate diameter, average tube length, and average cell aggregate diameter remained unchanged. In MPAEC, extracellular ATP $(100 \mu \mathrm{M})$ had only a negligible effect on network formation (Fig. 4b-e).

Extracellular ATP robustly activates ERK1/2, PI3K, and mTOR signaling pathways in VVEC but only modestly in AOEC and MPAEC

Studies in vivo and in vitro have shown the importance of ERK1/2 and PI3K/mTOR pathways in controlling angiogenesis-related events and metastatic tumor growth [3640]. Because of the differences in ATP-induced proliferative and migratory responses in VVEC, AOEC, and MPAEC, we examined the effects of ATP on activation of ERK1/2 (as measured by Thr202/Tyr204 phosphorylation), Akt (as measured by Ser473 phosphorylation), mTOR (as measured by Ser2448 phosphorylation), and p70S6K (as measured by Thr421/Ser424 phosphorylation) in the 
Fig. 3 Extracellular ATP induces migration of VVEC but not AOEC and MPAEC. Panels $\mathbf{a}$ and $\mathbf{b}$ : Growth-arrested VVEC were plated $(100,000$ cells/well $)$ in permeable inserts (Falcon ${ }^{\mathrm{TM}}$, $8.0 \mu \mathrm{M}$ pore size) in serum-free DMEM. The lower transwell compartment contained DMEM (a), DMEM and $100 \mu \mathrm{M}$ ATP (b), DMEM and 2\% FBS (c), or DMEM with $2 \%$ FBS and $100 \mu \mathrm{M}$ ATP (d). After $24 \mathrm{~h}$, cells remaining on the top of filter were wiped off, and cells on the bottom were fixed with methanol, stained with $2 \%$ crystal violet, and examined on a phase contrast microscope at $10 \times$ magnification.

Representative images show cells that migrated to the lower side of the filter. Panel c: Growth-arrested VVEC, AOEC, or MPAEC $(100,000$ cells/well) were submitted to the migration assay for $24 \mathrm{~h}$ as described above. Quantitative data on Panels $\mathbf{b}$ and $\mathbf{c}$ are means $\pm \mathrm{SE}$ from four distinct VVEC populations and two distinct AOEC and MPAEC populations; $* P<0.05$ vs. nonstimulated control
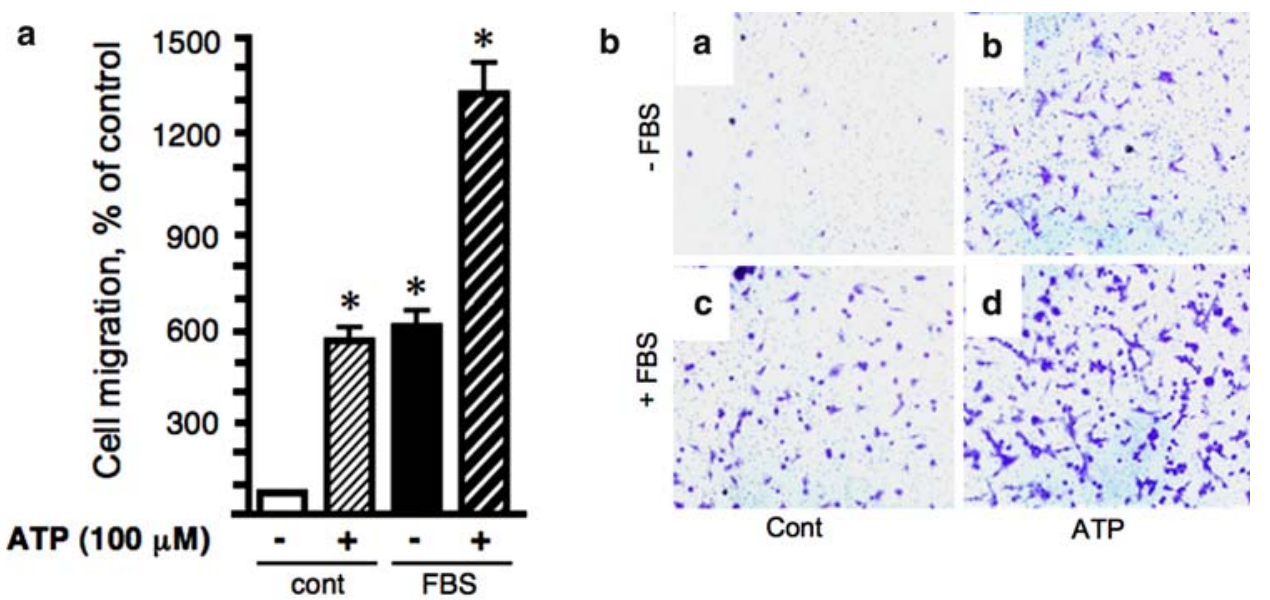

different endothelial cell types (Fig. 5). We found that ATP induced a greater stimulation of all examined signaling pathways in VVEC than in AOEC or MPAEC (Fig. 5). In particular, ATP exerted greater (maximum 10.8 fold increase) and more prolonged increase in phosphorylation of ERK1/2 in VVEC than in AOEC (maximum 4.2-fold) and in MPAEC (maximum 5.0-fold). ATP-induced phosphorylation of ERK1/2 was consistently observed in VVEC at $120 \mathrm{~min}$ and was not observed at this time point in AOEC or MPAEC. ATP-induced phosphorylation of Akt occurred earlier and was greater in VVEC than in AOEC and MPAEC (maximal fold increase 5.3, 3.2, and 2.4, respectively). ATP-induced phosphorylation of mTOR was greater in VVEC than in AOEC and MPAEC (maximal fold increase 4.8, 1.8, and 2.2, respectively). Maximal phosphorylation of p70S6K was also greater and more prolonged in VVEC than in AOEC and MPAEC (maximal fold increase 8.9, 2.0, and 2.4, respectively) Thus, in aggreement with the robust effect of extracellular ATP on DNA synthesis, these data support the idea that in adventitial VVEC, ERK1/2, PI3K/Akt, and mTOR/p70S6K pathways contribute to the ATP-dependent pro-angiogenic phenotype.
Because of the dramatic differences in the activation of Akt and mTOR/p70S6K pathways observed in VVEC in response to ATP, we sought to further characterize specific upstream events associated with ATP-induced mitogenesis. It is known that isoforms of class I PI3K containing p110 $\beta$ catalytic subunit and class II PI3K containing p101 $\gamma$ adaptor protein could be activated in a G-protein-dependent manner $[43,44]$. To demonstrate that activation of PI3K is an important early signaling event in ATP-mediated VVEC activation, we measured PI3K activity in an in vitro kinase assay. In these studies, quiescent cells were stimulated with ATP $(100 \mu \mathrm{M})$ for $30 \mathrm{~min}$, and total cell lysates were used for immunoprecipitation with anti-p85 regulatory subunit, $\mathrm{p} 110 \alpha$, anti-p110 $\beta$, anti-p110 $\delta$ catalytic subunit, or antip101 $\gamma$ adaptor protein-specific antibodies. We found that PI3K activity was associated with $\mathrm{p} 85, \mathrm{p} 110 \beta, \mathrm{p} 101 \gamma$, and p110 $\delta$ immunoprecipitates (Fig. 6). Inducing accumulation of phosphatidylinositol-3-phosphate (PtdIns-3(P)), the product of lipid kinase activity was observed in $\mathrm{p} 85$ and p110 $\beta$ immunoprecipitates, thus indicating class I PI3K $\beta$ in mediation of the effects of extracellular ATP in VVEC. The increase of $\mathrm{PI} 3 \mathrm{~K}$ activity associated with $\mathrm{p} 85$ regulatory subunit in response to ATP was comparable in magnitude to 
Fig. 4 Extracellular ATP induces VVEC but not AOEC and MPAEC rearrangements into tube-like networks on Matrigel. Panel a: Growtharrested VVEC (125,000 cells/ well in 24-well plate), AOEC, or MPAEC $(250,000$ cells/well in 24-well plate), were plated on growth factor reduced Matrigel in serum-free DMEM either with or without ATP $(100 \mu \mathrm{M})$. Cells were incubated for $8-$ $10 \mathrm{~h}$, and photographs were taken in three fields with a phase contrast microscope at $10 \times$ magnification. Representative images are shown for each cell type. Panels b-e: Images were analyzed using AxioVision as described in Section "Materials and methods". Quantitative data represent the means \pm SE from at least three experiments on two distinct cell populations; $* P<0.05$ vs. nonstimulated control a
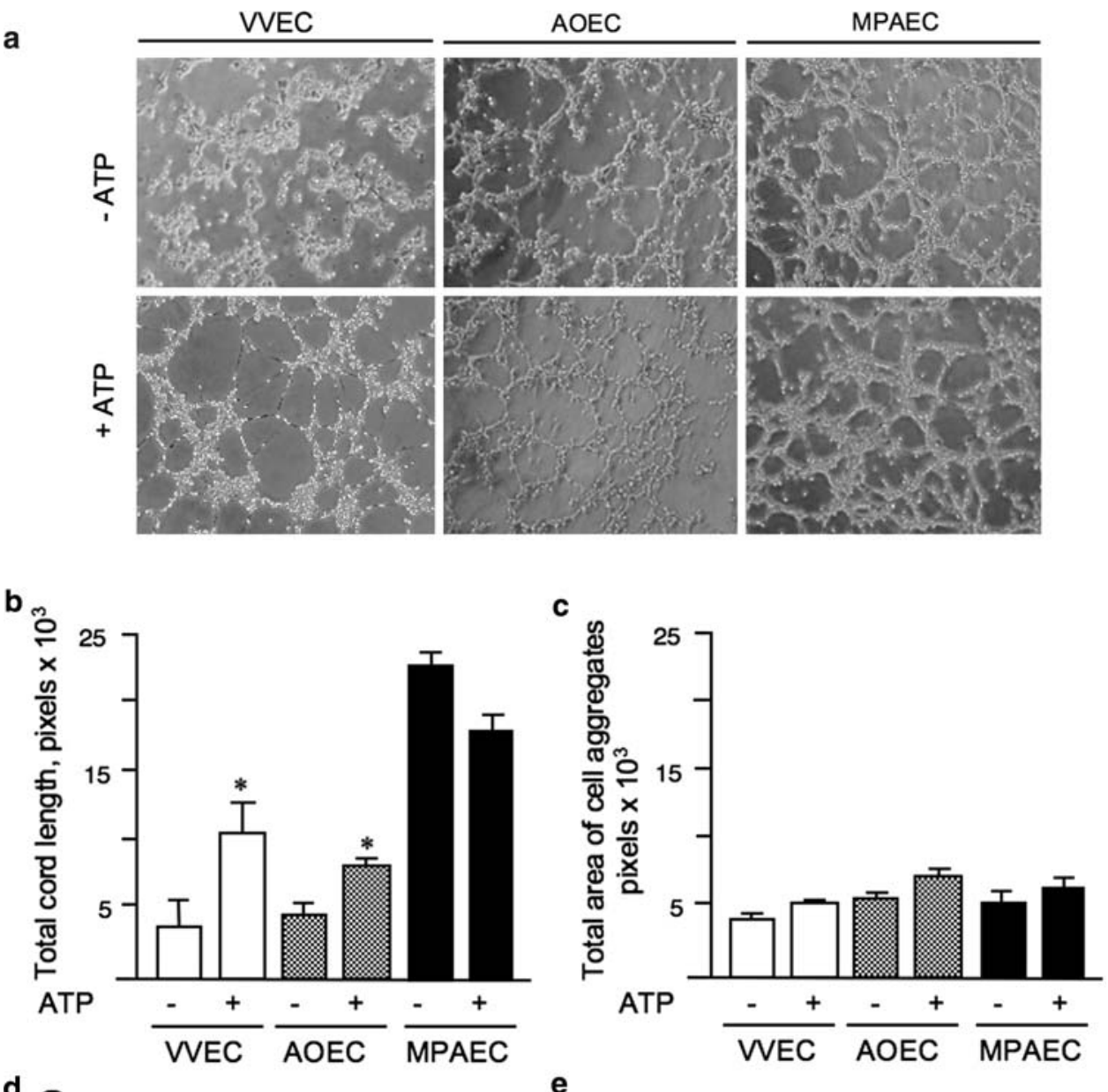

d
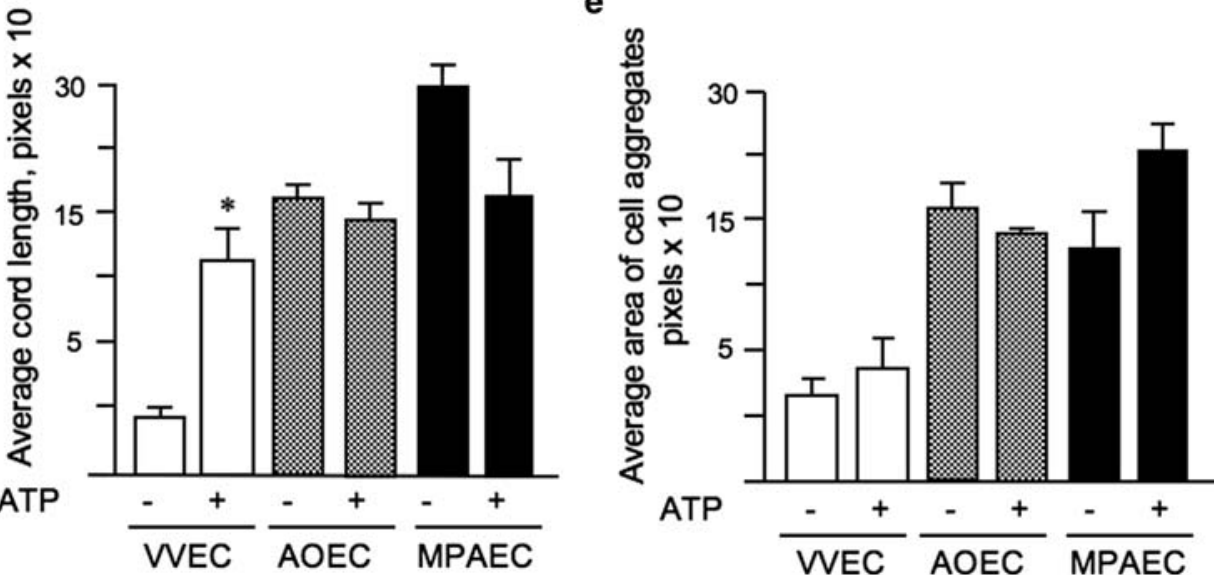

the effect of $10 \%$ fetal bovine serum, used in our experiments as a positive control to evaluate the maximal stimulatory effect. No detectable activity has been associated with $\mathrm{p} 110 \alpha$ immunoprecipitates. This is consistent with the role of $\mathrm{PI} 3 \mathrm{~K} \alpha$ isoform in mediating the signaling from receptor tyrosine kinases, but not $\mathrm{G}$ protein-coupled receptors. Significant accumulation of PtdIns-3(P) was detected in $\mathrm{p} 110 \delta$ and $\mathrm{p} 101 \gamma$ immunoprecipitates obtained from the control and ATP-stimulated cells, indicating that these isoforms are also expressed in VVEC and might play a distinct functional role.
PI3K/Akt, mTOR/p70S6K, and ERK1/2 pathways play a critical role in extracellular ATP-induced DNA synthesis and migration in VVEC

We next determined whether activation of PI3K/Akt, mTOR/p70S6K, and ERK1/2 pathway is necessary for ATP-induced DNA synthesis in VVEC. As shown in Fig. 7, pre-treatment of quiescent endothelial cells with the PI3K inhibitor LY294002 $(20 \mu \mathrm{M})$ and the MEK1/2 inhibitor U0126 (10 $\mu \mathrm{M})$ completely abolished ATP- 

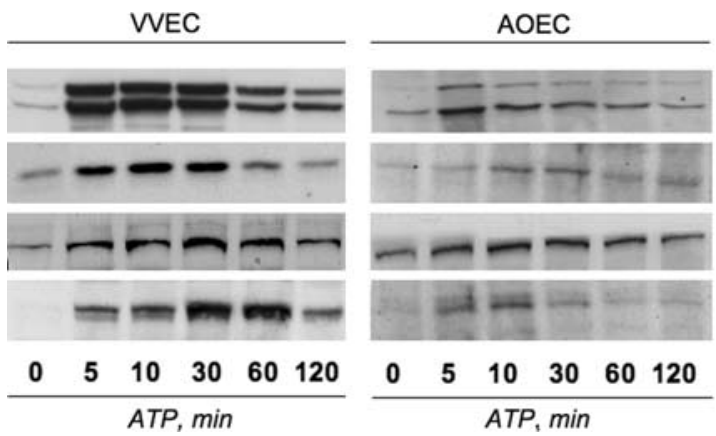

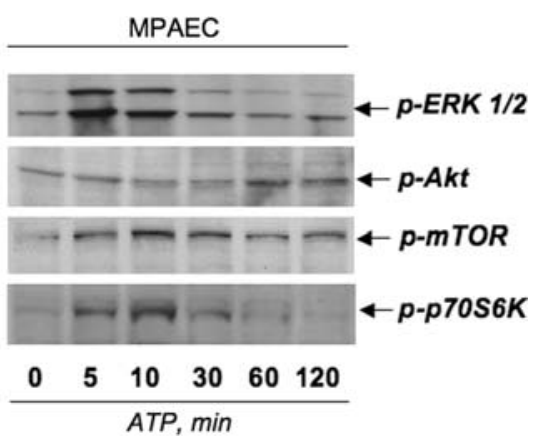

Fig. 5 Extracellular ATP robustly activates ERK1/2, PI3K/Akt, and $\mathrm{mTO} / \mathrm{p} 70 \mathrm{~S} 6 \mathrm{~K}$ signaling pathways in VVEC but only modestly in AOEC and MPAEC. Growth- arrested cells were stimulated with ATP $(100 \mu \mathrm{M})$ for the indicated times. Equivalent amounts of total cell protein $(25-40 \mu \mathrm{g})$ were subjected to Western blot analysis with antibodies against phospho-ERK1/2 (Thr202/Tyr204), phospho-Akt

induced increase in $\left[{ }^{3} \mathrm{H}\right.$-methyl]-thymidine incorporation. Pre-treatment with PI3K inhibitor wortmannin $(100 \mathrm{nM})$ and the inhibitor of mTOR pathway rapamycin $(10 \mathrm{nM})$, partially, but significantly attenuated the response. These data confirm that $\mathrm{PI} 3 \mathrm{~K} / \mathrm{mTOR}$ and ERK1/2 pathways are functionally involved in ATP-induced mitogenic signaling events in VVEC.

Similarly, pre-incubation of VVEC with LY294002, wortmannin, and U0126 significantly diminished ATPinduced migration. Rapamycin had a partial, but significant inhibitory effect on VVEC migration (Fig. 8). Consistent with the role of PI3K/mTOR and ERK1/2 in VVEC proliferation, these data demonstrate that activation of these pathways is also critically important to extracellular ATP-induced VVEC migration.

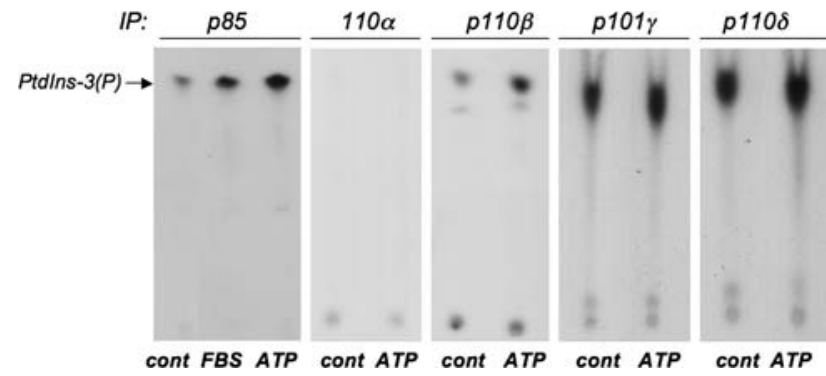

Fig. 6 Extracellular ATP increases PI3K activity in VVEC. Growtharrested cells DMEM were stimulated with ATP $(100 \mu \mathrm{M})$ for $30 \mathrm{~min}$. Equivalent amount of total cell protein $(500-750 \mu \mathrm{g})$ was immunoprecipitated with rabbit polyclonal antibodies against the $\mathrm{p} 85 \alpha$ regulatory subunit of $\mathrm{PI} 3 \mathrm{~K}, \mathrm{p} 110 \alpha, \mathrm{p} 110 \beta$, and $\mathrm{p} 110 \delta$ catalytic subunits, or against the p101 $\gamma$ adaptor protein. PI3K activity was measured in in vitro kinase assay with a $\mathrm{L}$ - $\alpha$-phosphatidylinositol (PtdIns) as a substrate. Arrow indicates the accumulation of a product of PI3K activity, PtdIns(3)P
(Ser 473), phospho-mTOR (Thr 2448), and phospho-p70S6K (Thr421/Ser424). Data shown on each panel illustrate representative experiments for each cell type. Similar results were reproduced in at least three independent experiments. The maximal phosphorylation responses observed within the indicated time frame, are discussed in the text

ERK1/2 pathway, but not PI3K/mTOR pathways play a critical role in extracellular ATP-induced formation of the tube-like networks in VVEC

Because cell rearrangement in the tube-like networks requires a proper cell migration, we sought to determine if $\mathrm{PI} 3 \mathrm{~K} / \mathrm{mTOR}$ and ERK1/2 pathways, are important to this response. We found that pre-incubation of VVEC with PI3K and mTOR pathway-specific inhibitors (LY294002, wortmannin, rapamycin) had only minor effects in ATP-

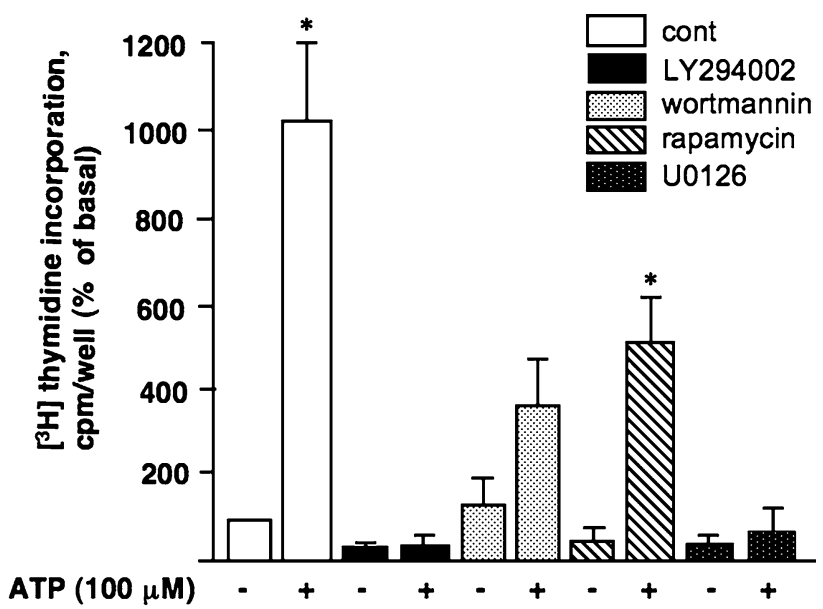

Fig. 7 PI3K/Akt, mTOR/p70S6K, and ERK1/2 pathways play a critical role in extracellular ATP-induced DNA synthesis in VVEC. Growth-arrested VVEC were preincubated with either LY294002 $(20 \mu \mathrm{M}, 60 \mathrm{~min})$, wortmannin $(100 \mathrm{nM}, 120 \mathrm{~min})$, rapamycin (10 nM, $60 \mathrm{~min})$, U0126 $(10 \mu \mathrm{M}, 60 \mathrm{~min})$, or vechicle followed by stimulation with ATP $(100 \mu \mathrm{M})$ in the presence of $0.125 \mu \mathrm{Ci}\left[{ }^{3} \mathrm{H}\right]-$ thymidine for $24 \mathrm{~h}$. Incorporated radioactivity was determined in total cell lysates as described in Materials and Methods. Results are expressed as percentage of basal thymidine incorporation in control cells. Data represent the means $\pm \mathrm{SE}$ from three to five independent experiments conducted on three distinct cell populations; ${ }^{*} P<0.05$ vs. nonstimulated control 


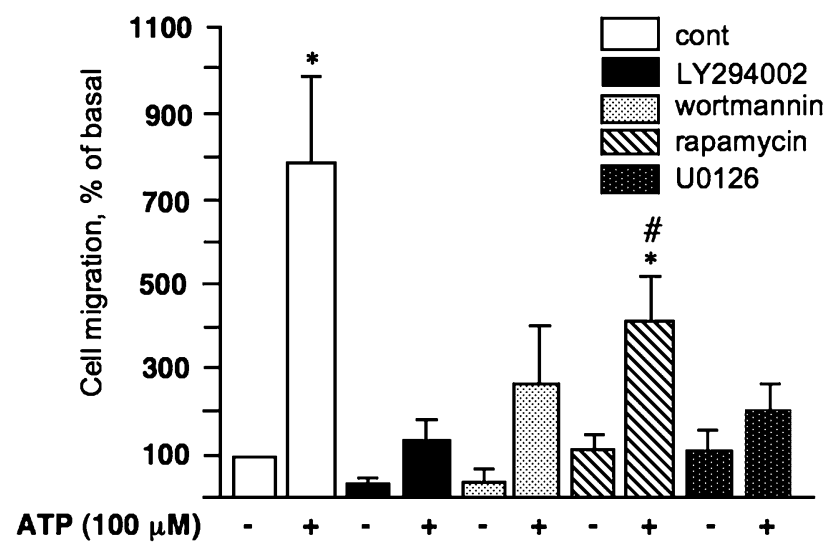

Fig. $8 \mathrm{PI} 3 \mathrm{~K} / \mathrm{Akt}$, ERK1/2, and mTOR/p70S6K pathways play a critical role in extracellular ATP-induced VVEC migration. Growth arrested VVEC (100,000 cells/well) were plated on top of inserts in serum free DMEM. Cells were preincubated with LY294002 (20 $\mu \mathrm{M}$, $60 \mathrm{~min})$ rapamycin $(10 \mathrm{nM}, 60 \mathrm{~min})$, wortmannin $(100 \mathrm{nM}$, $120 \mathrm{~min})$, U0126 (10 $\mu \mathrm{M}, 60 \mathrm{~min})$, or vechicle for $60 \mathrm{~min}$. Cell migration was stimulated by adding ATP $(100 \mu \mathrm{M})$ in the lower transwell compartment. At the end of incubation, cells on the bottom of filter were fixed and counted in three fields at $10 \mathrm{X}$ magnification. Quantitative data for each experimental condition represent the means \pm SE Similar results were reproduced in at least three experiments on four distinct cell populations; $* P<0.05$ vs. nonstimulated control; ${ }^{\#} P<0.05$ vs. ATP-stimulated cells

stimulated cells. (Fig. 9). Calculation of the areas occupied by the tube-like structures (total tube length and total cell aggregate diameter) indicated that there were no statistically significant contributions of PI3K and mTOR/p70S6K pathways to ATP-induced formation of VVEC networks. (Fig 9b-e). A small, but statistically significant effect on the total and average tube length was observed in U0126treated cell pointing out a role for ERK1/2 in this response (Fig 9a, b). These findings suggest that extracellular ATP-induced VVEC rearrangements in the tube-like networks requires additional, as yet unidentified intracellular signaling pathways.

\section{Discussion}

Pathologic angiogenesis plays a pivotal role in the progression of a variety of diseases. Our previous work has demonstrated that neonatal hypoxic pulmonary arterial hypertension is a condition involving pulmonary artery adventitial thickening, accumulation of inflammatory blood cells, and neovascularization of the adventitial vasa vasorum [3, 4]. Although many factors with angiogenic potential have been described, factors specifically involved in hypoxia-induced expansion of the vasa vasorum neovascularization in the PA have not been delineated. The findings of the present study provide strong support for the idea that extracellular ATP, potentially released from a variety of cells in the adventitia, including the vasa vasorum endothelial cells themselves, may be involved in this process. Our findings consistently showed that extracellular ATP robustly stimulated angiogenic responses, i.e., proliferation, migration, and network formation in Matrigel in VVEC derived from at least six different chronically hypoxic animals with pulmonary hypertension, adventitial remodeling, and vasa vasorum expansion. Interestingly, ATP had little angiogenic effects on main pulmonary artery endothelial cells or aortic endothelial cells isolated from the same animals. Importantly in VVEC, extracellular ATP potentiates the effect of VEGF and bFGF, other angiogenic factors known to be produced in hypoxic microenvironment. We found that ATP activated ERK1/2, PI3K/Akt, and $\mathrm{mTOR} / \mathrm{p} 70 \mathrm{~S} 6 \mathrm{~K}$ to a greater degree in VVEC than in AOEC and MPAEC, and that these signaling pathways are critical in ATP-induced proliferative and migratory responses in VVEC. Collectively, our data support the idea that extracellular ATP participates in the expansion of the vasa vasorum that is observed in the pulmonary artery adventitia of chronically hypoxic neonatal calves.

Although extracellular nucleotide-mediated signaling has been implicated in various physiological and pathologic conditions, there is limited information regarding the role of extracellular nucleotides in modulating endothelial cell proliferation. We found that extracellular ATP stimulates dramatic increases in DNA synthesis in VVEC, but has very little effect on AOEC and MPAEC isolated from the same animals. The exceptional sensitivity of microvascular endothelial cells to stimulation with ATP is supported by other studies showing a mitogenic effect of extracellular ATP, UTP, and 2MeSATP on brain capillary and corneal endothelial cells [45, 46]. The exaggerated responses to extracellular ATP suggest that VVEC may be abundantly equipped with multiple purinergic receptors. However, unexpectedly neither UTP nor UDP stimulated DNA synthesis in VVEC, though a previous report demonstrated both these pyrimidines stimulate guinea pig cardiac endothelial cell proliferation [23]. Analysis of nucleotide efficacy revealed that the P2Y1 family of purinergic receptors, $\mathrm{P} 2 \mathrm{Y} 1, \mathrm{P} 2 \mathrm{Y} 11, \mathrm{P} 2 \mathrm{Y} 12$, and $\mathrm{P} 2 \mathrm{Y} 13$ and perhaps, $\mathrm{P} 1$ adenosine receptors, but not pyrimidine $\mathrm{P} 2 \mathrm{Y} 4$ and P2Y6 receptors, play a predominant role in VVEC mitogenesis. Thus, VVEC appears to display a distinct phenotype characterized by the expression of a specific subset of purinergic receptors. Interestingly, expression of the subsets of P2Y1-like purinergic receptors has been reported for several types of immune and circulating blood cells [24]. When considered in the context of our previous findings demonstrating the presence of c-kit + cells in the newly expanding vasa vasorum [3], these data support the idea that vasa vasorum neovascularization might involve both angiogenesis and vasculogenic processes and that extracellular ATP could be involved in both. 
a

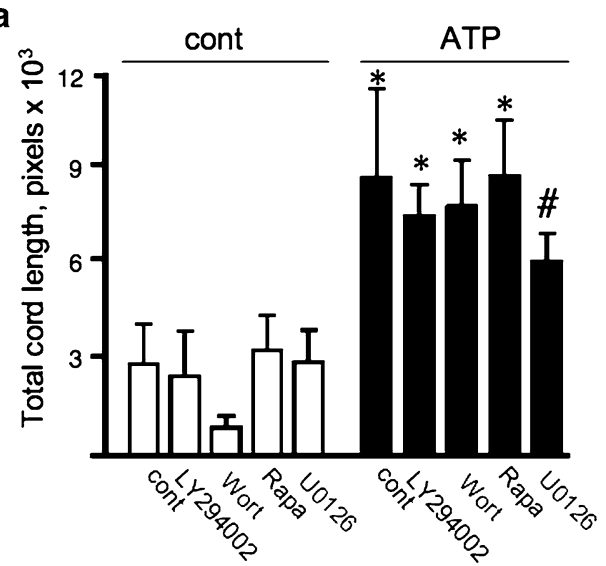

b

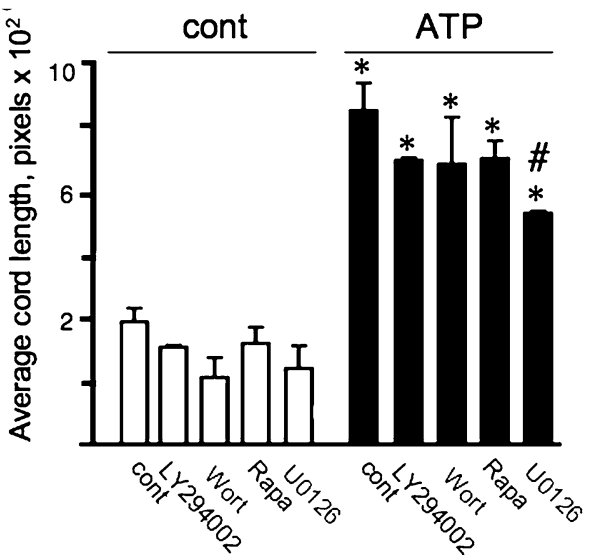

Fig. 9 Extracellular ATP induces VVEC network formation through activation of ERK1/2, and not of PI3K/mTOR pathways. Panels a-d: Growth-arrested VVEC (125,000 cells/well) were plated on growthfactor-reduced Matrigel in serum free DMEM. Cells were preincubated with LY294002 $(20 \mu \mathrm{M}, 60 \mathrm{~min})$ rapamycin $(10 \mathrm{nM}$, $60 \mathrm{~min})$, wortmannin $(100 \mathrm{nM}, 120 \mathrm{~min}), \mathrm{U} 0126(10 \mu \mathrm{M}, 60 \mathrm{~min})$, or vechicle for $60 \mathrm{~min}$. Formation of tube-like networks was

Previous studies have demonstrated that endothelial cells derived from large vessels express several types of purinergic receptors. Expression of $\mathrm{P} 2 \mathrm{Y} 1$ and $\mathrm{P} 2 \mathrm{Y} 2$ receptors has been shown in bovine aortic endothelial cells and expression of P2Y1, P2Y2, P2Y6, P2X4, and P2X5 receptors documented in human umbilical vein endothelial cells [47, 48]. Activation of P2 receptors in these cells mediates the release of nitric oxide, endothelium-dependent hyperpolarizing factor (EDHF), prostacyclin, and t-PA [47]. Similar to our observations in AOEC and MPAEC, Daele et al. have found that ATP and synthetic P2Y receptor agonists exerted only weak increases in DNA synthesis in bovine aortic endothelial cells [49]. In addition to adenine nucleotides, pyrimidine nucleotides, UTP and UDP have been shown to exert mitogenic and chemotactic effects on human umbilical vein and guinee pig cardiac endothelial cells [20, 23]. However, in our studies we did not observe any stimulatory effect of UTP and UDP, on
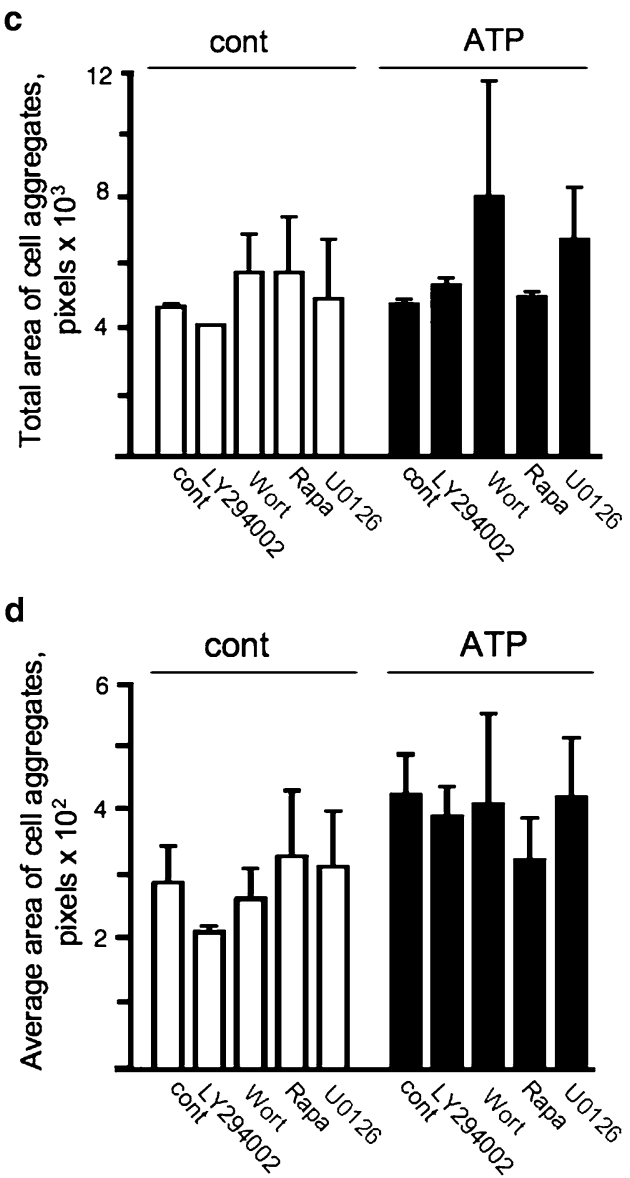

stimulated by the addition ATP $(100 \mu \mathrm{M})$. At the end of incubation, images were captured in three fields using AxioVision program. Quantitative data for total and average tube (cord) lengths and area of cell aggregates represent the means \pm SE. Similar results were reproduced in at least three experiments on three distinct cell populations; $* P<0.05$ vs. nonstimulated control; ${ }^{\#} P<0.05$ vs. ATP stimulated-cells

DNA synthesis in any of the examined endothelial cell types. Thus our data, when combined with that from other reports, suggest that there must be tremendous heterogeneity in endothelial phenotypes, with regard to extracellular nucleotide-induced functional responses and the signaling pathways through which these effects are mediated.

To further investigate the possibility that differences in post-receptor signaling events in VVEC, AOEC and MPAEC might be involved in conferring distinct proliferative and migratory phenotypes, we evaluated the activation of intracellular kinases downstream of $\mathrm{P} 2 \mathrm{Y}$ receptors. We found significant differences in the magnitude and duration of activation of ERK1/2, Akt, mTOR, and p70S6K between VVEC and AOEC and MPAEC. Greater and more prolonged activation of EKR1/2 and p70S6K in VVEC could contribute to proliferative and migratory advantages. In fact, we demonstrated that 
blockade of these pathways inhibited proliferation and migration. Interestingly, we also observed that ATP in combination with VEGF or bFGF resulted in more dramatic induction of DNA synthesis in VVEC than in other endothelial cell types. This observation suggests that under conditions of chronic hypoxia, the simultaneous release of mitogenic growth factors and nucleotides from vascular and circulating blood cells may result in cumulative stimulatory effects on proliferation and migration of specific endothelial cells, in our case the VVEC.

Enzymatic reactions contributing to the pathways of extracellular ATP synthesis and degradation play a critical role in regulating the concentration of extracellular ATP and its metabolites near purinergic receptors. Recent studies have implicated the endothelial cell surface ecto$\mathrm{F}_{1}-\mathrm{F}_{0}$ ATP synthase in endothelial cell and tumor cell proliferation $[50,51]$. It has been shown that both angiostatin and monoclonal antibodies directed against the $\beta$ subunit of ecto- $\mathrm{F}_{1}-\mathrm{F}_{0}$ ATP synthase-inhibited human umbilical vein endothelial cell proliferation through inactivation of extracellular ATP synthetic pathway [52]. Intringingly, endothelial progenitor cells were found to be more sensitive to angiostatin than mature endothelial cells [53]. Given the observations that ATP seems to exert such potent effects on VVEC proliferation as well as the possibility that circulating endothelial precursors might be incorporated at the sites of neovascularization [3], future experiments directed at an evaluation of ATP synthesis and degradation pathways on VVEC surface will be important.

Morphogenetic changes in endothelial cells are critical for appropriate assembly in newly forming blood vessels. It is believed that formation of a tube-like intercellular network on basement membrane matrix (Matrigel) reflects the ability of endothelial cells to undergo differentiation. To date, there have been no studies to demonstrate the effect of extracellular ATP on endothelial rearrengement into the tube-like networks. Using in vitro Matrigel assay on growth factor-reduced matrix, we demonstrated that extracellular ATP exerted significant effects on VVEC tube-like network formation. Interestingly, under basal conditions, AOEC and MPAEC rearrange in tube-like networks with a patterns different than those observed for VVEC. However, in contrast to VVEC, ATP did not exert significant effects on tube-like formation in these cells. The reasons for these different responses in Matrigel under both basal and ATP-stimulated conditions exhibited by the different cell types remain unclear and will require future investigation. They do, however, reinforce the idea that endothelial cells isolated from different vascular beds, maintain distinct functional characteristics even after being perpetuated in culture. The maintenance of these differences will allow evaluation of vascular bed-specific endothelial phenotypes in vitro [54].
Characterization of the signaling pathways contributing to angiogenesis is important in developing pharmacologic strategies for both pro- and anti-angiogenic therapy. It has been shown that constitutive activation of PI3K/Akt/mTOR and ERK pathways is observed under various pathological conditions associated with chronic hypoxia, inflammation, and cancer, suggesting that in the hypoxic adventitial microenvironment, these pathways could play a permissive role for vasa vasorum growth [43, 55-57]. It has been previously reported by others and us that ERK1/2 and PI3K pathways play a critical role in extracellular ATP-induced proliferation of smooth muscle and fibroblasts [31, 41, 42, 58]. However, the involvement of PI3K and mTOR pathways in nucleotide-mediated angiogenic responses in endothelial cells has not been fully investigated. The results of our studies demonstrate that extracellular ATP activates PI3K/Akt, mTOR/p70S6K, and ERK1/2 pathways in VVEC and that activation of these pathways contributes to VVEC mitogenic and migratory responses. Using PI3K isoform-specific antibodies and in vitro kinase assay, we found that ATP-stimulated PI3K activity is selectively associated with the $\mathrm{p} 85$ regulatory subunit and $\mathrm{p} 110 \beta$ catalytic subunit, indicating that at least class $\mathrm{I} P \mathrm{PI} K \beta$ is involved in ATP-induced mitogenic signaling events in VVEC. Our observations also suggest a possibility that $\mathrm{PI} 3 \mathrm{~K} \delta$, an isoform expressed predominantly in hematopoietic cells, may play a role in mediating the effects of extracellular ATP and/or another angiogenic factors in VVEC. Complementary to our findings on the role of PI3K pathway in endothelial angiogenic responses, studies on human umbilical vein endothelial cells (HUVEC) demonstrated the involvement of PI3K, focal adhesion kinase, p130 ${ }^{\text {cas }}$, and paxillin in extracellular ATP- and UTP-mediated cell migration [20]. In addition, activation of ERK and $\mathrm{PI} 3 \mathrm{~K} / \mathrm{PDK} / \mathrm{PKC}$ pathways in response to $\mathrm{P} 2 \mathrm{Y}$ receptor agonists was demonstrated in HUVEC and in U138-MG human glyoma cell line, demonstrating the ubiquitous role of extracellular nucleotides and associated PI3K-dependent pathways in regulating growth responses. Finally, our data demonstrate that ERK1/2, but not PI3K and mTOR, contributes to extracellular ATP-induced VVEC rearrangement into tube-like networks in Matrigel, suggesting that additional, as yet unidentified signaling pathways are involved in endothelial tubulogenesis. Recent observations in aortic and lung microvascular endothelial cells demonstrate that PLC $\gamma / \mathrm{Ca}^{2+}$ and cAMP/ERK1/2 pathways may be considered for their role in the endothelial tube-like formation [59, 60]. Because ATP-mediated activation of VVEC involves increases in intracellular $\mathrm{Ca}^{2+}$ level (unpublished observation), evaluation of $\mathrm{PLC} / \mathrm{Ca}^{2+}$ pathway will be an important focus of future studies.

In conclusion, our findings also demonstrate that extracellular ATP is potent angiogenic factor for VVEC, but not 
for endothelial cells derived from large systemic and pulmonary vessels, such as aorta and main pulmonary artery. The dramatic effect of extracellular ATP on the activation of PI3K/Akt/mTOR and ERK1/2 pathways suggests that in VVEC, expression of the components of these signaling pathways together with P2Y1 purinergic receptors, contributes to a pro-angiogenic phenotype. Finally, the results of our studies indicate potential significance for antiangiogenic therapy, in which a combination of purinergic receptor antagonists with $\mathrm{PI} 3 \mathrm{~K} / \mathrm{mTOR}$ - and ERK1/2-specific inhibitors may be considered for eliminating neovessel growth under pathological conditions where elevated levels of extracellular ATP and the other purine nucleotides can be expected.

Acknowledgments This work is supported by an American Heart Association Beginning Grant-in-Aid 0665464Z (to E.V.G) and by National Heart, Lung, and Blood Institute Program Project Grant HL 14985 (to K.R.S). We thank Dr. Suzette Riddle for help with endothelial cell cultures. We thank Dr. David Lewis and Dr. Marina Lewis for editorial help.

Open Access This article is distributed under the terms of the Creative Commons Attribution Noncommercial License which permits any noncommercial use, distribution, and reproduction in any medium, provided the original author(s) and source are credited.

\section{References}

1. Carmeliet P (2003) Angiogenesis in health and disease. Nat Med 9:635-660

2. Bicknell R, Harris AL (2004) Novel angiogenic signaling pathways and vascular targets. Annu Rev Pharmacol Toxicol 44:219-238

3. Davie NJ, Crossno JT Jr., Frid MG, Hofmeister SE, Reeves JT, Hyde DM, Carpenter TC, Brunetti JA, McNiece IK, Stenmark KR (2004) Hypoxia-induced pulmonary artery adventitial remodeling and neovascularization: contribution of progenitor cells. Am J Physiol Lung Cell Mol Physiol 286:L668-L678

4. Stenmark KR, Fagan KA, Frid MG (2006) Hypoxia-induced pulmonary vascular remodeling: cellular and molecular mechanisms. Circ Res 99:675-691

5. Fuchs S, Kornowski R, Leon MB, Epstein SE (2001) Antiangiogenesis: a new potential strategy to inhibit restenosis. Int $\mathbf{J}$ Cardiovasc Intervent 4:3-6

6. Moulton KS, Vakili K, Zurakowski D, Soliman M, Butterfield C, Sylvin E, Lo KM, Gillies S, Javaherian K, Folkman J (2003) Inhibition of plaque neovascularization reduces macrophage accumulation and progression of advanced atherosclerosis. Proc Natl Acad Sci USA 100:4736-4741

7. Numano F (2000) Vasa vasoritis, vasculitis and atherosclerosis. Int J Cardiol 75(Suppl 1):S1-S8; discussion S17-19

8. Fukushi J, Ono M, Morikawa W, Iwamoto Y, Kuwano M (2006) The activity of soluble VCAM-1 in angiogenesis stimulated by IL-4 and IL-13. J Immunol 165:2818-2823

9. Hartlapp I, Abe R, Saeed RW, Peng T, Voelter W, Bucala R, Metz CN (2001) Fibrocytes induce an angiogenic phenotype in cultured endothelial cells and promote angiogenesis in vivo. FASEB J 15:2215-2224

10. Liekens S, De Clercq E, Neyts J (2001) Angiogenesis: regulators and clinical applications. Biochem Pharmacol 61:253-270
11. Seghezzi G, Patel S, Ren CJ, Gualandris A, Pintucci G, Robbins ES, Shapiro RL, Galloway AC, Rifkin DB, Mignatti P (1998) Fibroblast growth factor-2 (FGF-2) induces vascular endothelial growth factor (VEGF) expression in the endothelial cells of forming capillaries: an autocrine mechanism contributing to angiogenesis. J Cell Biol 141:1659-1673

12. Yonekura H, Sakurai S, Liu X, Migita H, Wang H, Yamagishi S, Nomura M, Abedin MJ, Unoki H, Yamamoto Y, Yamamoto $\mathrm{H}$ (1999) Placenta growth factor and vascular endothelial growth factor B and C expression in microvascular endothelial cells and pericytes: implication in autocrine and paracrine regulation of angiogenesis. J Biol Chem 274:35172-35178

13. Burnstock G (2002) Purinergic signaling and vascular cell proliferation and death. Arterioscler Thromb Vasc Biol 22:364-373

14. Di Virgilio F, Solini A (2002) P2 receptors: new potential players in atherosclerosis. Br J Pharmacol 135:831-842

15. Abbracchio MP, Burnstock G (1998) Purinergic signalling: pathophysiological roles. Jpn J Pharmacol 78:113-145

16. Koyama T, Oike M, Ito Y (2001) Involvement of Rho-kinase and tyrosine kinase in hypotonic stress-induced ATP release in bovine aortic endothelial cells. J Physiol 532:759-769

17. Ralevic V, Burnstock G (1998) Receptors for purines and pyrimidines. Pharmacol Rev 50:413-492

18. Jacobson JR, Dudek SM, Singleton PA, Kolosova IA, Verin AD, Garcia JGN (2006) Endothelial cell barrier enhancement by ATP is mediated by the small GTPase Rac and cortactin. Am J Physiol Lung Cell Mol Physiol 291:L289-295

19. Noll T, Hölschermann H, Koprek K, Gündüz D, Haberbosch W, Tillmanns H, Piper HM (1999) ATP reduces macromolecule permeability of endothelial monolayers despite increasing $\left[\mathrm{Ca}^{2+}\right]$. Am J Physiol 276:H1892-1901

20. Kaczmarek E, Erb L, Koziak K, Jarzyna R, Wink MR, Guckelberger O, Blusztajn JK, Trinkaus-Randall V, Weisman GA, Robson SC (2005) Modulation of endothelial cell migration by extracellular nucleotides: involvement of focal adhesion kinase and phosphatidylinositol 3-kinase-mediated pathways. Thromb Haemost 93:735-742

21. Lemoli RM, Ferrari D, Fogli M, Rossi L, Pizzirani C, Forchap S, Chiozzi P, Vaselli D, Bertolini F, Foutz T, Aluigi M, Baccarani M, Di Virgilio F (2004) Extracellular nucleotides are potent stimulators of human hematopoietic stem cells in vitro and in vivo. Blood 104:1662-1670

22. Rossi L, Manfredini R, Bertolini F, Ferrari D, Fogli M, Zini R, Salati S, Salvestrini V, Gulinelli S, Adinolfi E, Ferrari S, Di Virgilio F, Baccarani M, Lemoli RM (2007) The extracellular nucleotide UTP is a potent inducer of hematopoietic stem cell migration. Blood 109(2):533-42

23. Satterwhite CM, Farrelly AM, Bradley ME (1999) Chemotactic, mitogenic, and angiogenic actions of UTP on vascular endothelial cells. Am J Physiol 276:H1091-1097

24. Burnstock G (2006) Pathophysiology and therapeutic potential of purinergic signaling. Pharmacol Rev 58:58-86

25. Seye CI, Yu N, Gonzalez FA, Erb L, Weisman GA (2004) The P2Y2 nucleotide receptor mediates vascular cell adhesion molecule-1 expression through interaction with VEGF receptor-2 (KDR/Flk-1). J Biol Chem 279:35679-35686

26. Seye CI, Yu N, Jain R, Kong Q, Minor T, Newton J, Erb L, Gonzalez FA, Weisman GA (2003) The P2Y2 nucleotide receptor mediates UTP-induced vascular cell adhesion molecule-1 expression in coronary artery endothelial cells. J Biol Chem 278:24960-24965

27. Dubey RK, Gillespie DG, Jackson EK (2002) A(2B) adenosine receptors stimulate growth of porcine and rat arterial endothelial cells. Hypertension 39:530-535

28. Feoktistov I, Ryzhov S, Zhong H, Goldstein AE, Matafonov A, Zeng D, Biaggioni I (2004) Hypoxia modulates adenosine 
receptors in human endothelial and smooth muscle cells toward an A2B angiogenic phenotype. Hypertension 44:649-654

29. Grant MB, Davis MI, Caballero S, Feoktistov I, Biaggioni I, Belardinelli L (2001) Proliferation, migration, and ERK activation in human retinal endothelial cells through $\mathrm{A}(2 \mathrm{~B})$ adenosine receptor stimulation. Invest Ophthalmol Vis Sci 42:2068-2073

30. Erlinge D (1998) Extracellular ATP: a growth factor for vascular smooth muscle cells. Gen Pharmacol 31:1-8

31. Gerasimovskaya EV, Ahmad S, White CW, Jones PL, Carpenter TC, Stenmark KR (2002) Extracellular ATP is an autocrine/ paracrine regulator of hypoxia-induced adventitial fibroblast growth. Signaling through extracellular signal-regulated kinase-1/ 2 and the Egr-1 transcription factor. J Biol Chem 277:4463844650

32. Huang N, Wang DJ, Heppel LA (1989) Extracellular ATP is a mitogen for 3T3, 3T6, and A431 cells and acts synergistically with other growth factors. Proc Natl Acad Sci USA 86:79047908

33. Davie NJ, Gerasimovskaya EV, Hofmeister SE, Richman AP, Jones PL, Reeves JT, Stenmark KR (2006) Pulmonary artery adventitial fibroblasts cooperate with vasa vasorum endothelial cells to regulate vasa vasorum neovascularization: a process mediated by hypoxia and endothelin-1. Am J Pathol 168:17931807

34. Gerasimovskaya EV, Davie NJ, Ahmad S, Tucker DA, White CW, Stenmark KR (2005) Extracellular adenosine triphosphate: a potential regulator of vasa vasorum neovascularization in hypoxia-induced pulmonary vascular remodeling. Chest 128:608S-610S

35. Schwiebert LM, Rice WC, Kudlow BA, Taylor AL, Schwiebert EM (2002) Extracellular ATP signaling and P2X nucleotide receptors in monolayers of primary human vascular endothelial cells. Am J Physiol Cell Physiol 282:C289-C301

36. Guba M, von Breitenbuch P, Steinbauer M, Koehl G, Flegel S, Hornung M, Bruns CJ, Zuelke C, Farkas S, Anthuber M, Jauch KW, Geissler EK (2002) Rapamycin inhibits primary and metastatic tumor growth by antiangiogenesis: involvement of vascular endothelial growth factor. Nat Med 8:128-135

37. Hamada K, Takuwa N, Yokoyama K, Takuwa Y (1998) Stretch activates Jun $\mathrm{N}$-terminal kinase/stress-activated protein kinase in vascular smooth muscle cells through mechanisms involving autocrine ATP stimulation of purinoceptors. J Biol Chem 273:6334-6340

38. Kim SR, Bae SK, Choi KS, Park SY, Jun HO, Lee JY, Jang HO, Yun I, Yoon KH, Kim YJ, Yoo MA, Kim KW, Bae MK (2007) Visfatin promotes angiogenesis by activation of extracellular signal-regulated kinase 1/2. Biochem Biophys Res Commun 357:150-156

39. Li W, Petrimpol M, Molle KD, Hall MN, Battegay EJ, Humar R (2007) Hypoxia-induced endothelial proliferation requires both mTORC1 and mTORC2. Circ Res 100:79-87

40. Phung TL, Ziv K, Dabydeen D, Eyiah-Mensah G, Riveros M, Perruzzi C, Sun J, Monahan-Earley RA, Shiojima I, Nagy JA, Lin MI, Walsh K, Dvorak AM, Briscoe DM, Neeman M, Sessa WC, Dvorak HF, Benjamin LE (2006) Pathological angiogenesis is induced by sustained Akt signaling and inhibited by rapamycin. Cancer Cell 10:159-170

41. Das M, Bouchey DM, Moore MJ, Hopkins DC, Nemenoff RA, Stenmark KR (2001) Hypoxia-induced proliferative response of vascular adventitial fibroblasts is dependent on $\mathrm{g}$ protein-mediated activation of mitogen-activated protein kinases. J Biol Chem 276:15631-15640

42. Gerasimovskaya EV, Tucker DA, Weiser-Evans M, Wenzlau JM, Klemm DJ, Banks M, Stenmark KR (2005) Extracellular ATPinduced proliferation of adventitial fibroblasts requires phosphoinositide 3-kinase, Akt, mammalian target of rapamycin, and p70 S6 kinase signaling pathways. J Biol Chem 280:18381848

43. Engelman JA, Luo J, Cantley LC (2006) The evolution of phosphatidylinositol 3-kinases as regulators of growth and metabolism. Nat Rev Genet 7:606-619

44. Vanhaesebroeck B, Waterfield MD (1999) Signaling by distinct classes of phosphoinositide 3-kinases. Exp Cell Res 253:239-254

45. Albert JL, Boyle JP, Roberts JA, Challiss RA, Gubby SE, Boarder MR (1997) Regulation of brain capillary endothelial cells by P2Y receptors coupled to $\mathrm{Ca} 2+$, phospholipase $\mathrm{C}$ and mitogen-activated protein kinase. Br J Pharmacol 122:935-941

46. Cha SH, Hahn TW, Sekine T, Lee KH, Endou H (2000) Purinoceptor-mediated calcium mobilization and cellular proliferation in cultured bovine corneal endothelial cells. Jpn J Pharmacol 82:181-187

47. Wang L, Karlsson L, Moses S, Hultgårdh-Nilsson A, Andersson M, Borna C, Gudbjartsson T, Jern S, Erlinge D (2002) P2 receptor expression profiles in human vascular smooth muscle and endothelial cells. J Cardiovasc Pharmacol. 40:841-853

48. Motte S, Pirroton S, Boeynaems JM (1993) Heterogeneity of ATP receptors in aortic endothelial cells. Involvement of P2y and P2u receptors in inositol phosphate response. Circ Res 72:504-510

49. Van Daele P, Van Coevorden A, Roger PP, Boeynaems JM (1992) Effects of adenine nucleotides on the proliferation of aortic endothelial cells. Circ Res 70:82-90

50. Arakaki N, Nagao T, Niki R, Toyofuku A, Tanaka H, Kuramoto Y, Emoto Y, Shibata H, Magota K, Higuti T (2003) Possible role of cell surface H+ -ATP synthase in the extracellular ATP synthesis and proliferation of human umbilical vein endothelial cells. Mol Cancer Res 1:931-939

51. Chi SL, Pizzo SV (2006) Angiostatin is directly cytotoxic to tumor cells at low extracellular $\mathrm{pH}$ : a mechanism dependent on cell surface-associated ATP synthase. Cancer Res 66:875-882

52. Chi SL, Wahl ML, Mowery YM, Shan S, Mukhopadhyay S, Hilderbrand SC, Kenan DJ, Lipes BD, Johnson CE, Marusich MF, Capaldi RA, Dewhirst MW, Pizzo SV (2007) Angiostatinlike activity of a monoclonal antibody to the catalytic subunit of F1F0 ATP synthase. Cancer Res 67:4716-4724

53. Ito H, Rovira II, Bloom ML, Takeda K, Ferrans VJ, Quyyumi AA, Finkel T (1999) Endothelial progenitor cells as putative targets for angiostatin. Cancer Res. 59:5875-5877

54. Aird WC (2007) Phenotypic heterogeneity of the endothelium: I. Structure, function, and mechanisms. Circ Res 100:158-173

55. Faivre S, Kroemer G, Raymond E (2006) Current development of mTOR inhibitors as anticancer agents. Nat Rev Drug Discov 5:671-688

56. Granville CA, Memmott R, Gills JJ, Dennis PA (2006) Handicapping the race to develop inhibitors of the phosphoinositide 3kinase/Akt/mammalian target of rapamycin pathway. Clin Cancer Res 12:679-689

57. Wullschleger S, Loewith R, Hall MN (2006) TOR signaling in growth and metabolism. Cell 124:471-484

58. Wilden PA, Agazie YM, Kaufman R, Halenda SP (1998) ATPstimulated smooth muscle cell proliferation requires independent ERK and PI3K signaling pathways. Am J Physiol 275:H12091215

59. Meyer RD, Latz C, Rahimi N (2003) Recruitment and activation of phospholipase Cgamma1 by vascular endothelial growth factor receptor- 2 are required for tubulogenesis and differentiation of endothelial cells. J Biol Chem 278:16347-16355

60. Rao R, Redha R, Macias-Perez I, Su Y, Hao C, Zent R, Breyer MD, Pozzi A (2007) Prostaglandin E2-EP4 receptor promotes endothelial cell migration via ERK activation and angiogenesis in vivo. J Biol Chem 282:16959-16968 